\title{
OS PAPAS NA ONU E A DEFESA DOS DIREITOS HUMANOS
}

THE POPES AT THE UN AND THE DEFENCE OF HUMAN RIGHTS

Raphael Rego Borges Ribeiro*

\section{RESUMO}

Neste artigo, analisamos as manifestações dos Papas endereçadas à Assembleia Geral das Nações Unidas, buscando nelas identificar elementos de defesa dos Direitos Humanos. Recorremos à consulta a fontes primárias, especificamente os discursos de Paulo VI, João Paulo II, Bento XVI e Francisco à ONU. Utilizamos o método dedutivo para conduzir nossa análise. Tivemos como objetivo geral verificar se a Igreja Católica assumiu publicamente, à comunidade internacional, uma postura de defesa da humanidade. Observamos que todos os Papas abordaram diversos temas de Direitos Humanos. Notamos que Paulo VI e João Paulo Il focaram na promoção da paz, no combate à pobreza e na proteção à liberdade religiosa. Também percebemos que Bento XVI e Francisco, além de defender os tópicos trazidos pelos seus antecessores, também advogaram pela preservação ambiental.

Palavras-chave: Papa; Igreja Católica; Organização das Nações Unidas; Direitos Humanos; Direito Internacional.

\section{ABSTRACT}

In this paper, I analyzed the Popes' addresses to the United Nations General Assembly, trying to identify in them a defense of human rights. I looked into primary sources, specifically Paul VI's, John Paul II's, Benedict XVI's, and Francis's speeches at the UN. I used the deductive method to conduct my analysis. My main goal was checking whether the Catholic Church publicly stood, in relation to the international community, on behalf of humanity. I noticed that both Paul VI and John Paul I focused on the promotion of peace, the fight against poverty, and the protection of religious freedom. I also figured out that both Benedict XVI and Francis, besides defending the issues brought by their predecessors, advocated for environmental preservation as well.

Keywords: Pope; Catholic Church; United Nations; Human Rights; International Law.

* Doutor, Mestre e Bacharel em Direito pela Universidade Federal da Bahia.

Mestrando na University of Ottawa. Professor da Universidade Federal do Oeste da Bahia. raphael.ribeiro@ufob.edu.br 
INTRODUÇÃO; 1 PAULO VI; 2 JOÃO PAULO II; 2.1 Primeiro discurso: outubro de 1979; 2.2. Segundo discurso: outubro de 1995; 3 BENTO XVI; 4 FRANCISCO; CONSIDERAÇÕES FINAIS; REFERÊNCIAS.

\section{- INTRODUÇÃO}

A Igreja Católica é personificada pela Santa Sé, tendo como sede a Cidade do Vaticano, do qual o Papa é chefe de Estado. Por essa razão, o Pontífice não está subordinado interna ou internacionalmente a outro país. A Santa Sé é independente, autônoma e, consequentemente, sujeito de Direito Internacional. Assim, atua internacionalmente, celebrando tratados e exercendo direito de legação ${ }^{1}$. Do mesmo modo, consequentemente, tem representação e voz na Organização das Nações Unidas (ONU). Os discursos na ONU têm grande potencial de repercussão midiática, que tornam mais poderoso e efetivo o soft power que o Papa exerce sobre a comunidade internacional.

A presente pesquisa busca se orienta pela pergunta: o que os Papas tiveram a dizer sobre Direitos Humanos quando se dirigiram ao mundo da tribuna da Organização das Nações Unidas? Para responder tal questionamento, é explorado o conteúdo dos discursos dos discursos proferidos pelos pontífices Paulo VI, João Paulo II, Bento XVI e Francisco junto à Assembleia Geral da ONU.

O objetivo geral da pesquisa é encontrar nos discursos dos Papas à ONU um direcionamento que reflita o papel da Igreja Católica na construção dos Direitos Humanos na segunda metade do século XX e no início do século XXI. Como objetivos específicos, observaremos o conteúdo de cada uma das manifestações, identificando temas de Direitos Humanos e contextualizando-os tanto na época em que foram proferidas quanto no conjunto geral do ministério de cada pontífice.

A pesquisa se justifica na medida em que o Papa, sendo líder da Igreja Católica, atua diretamente na vida de milhões de pessoas, com capacidade de influenciar os direcionamentos de diversos assuntos caros à comunidade internacional. Sua autoridade moral pode chancelar ou condenar de comportamentos a regimes políticos. Por essa razão, é de fundamental importância que o Pontífice sempre se manifeste no sentido de denunciar abusos ou inspirar a paz, por exemplo. Nesse sentido, a Igreja sofre diversas críticas em razão da ausência de um posicionamento firme em direção contrária às atrocidades praticadas pelos regimes autoritários que despontaram na Europa Ocidental na primeira metade do século XX. Na verdade, o Papa Pio XI se manifestou abertamente contra o nazismo em sua encíclica Mit brennender

\footnotetext{
1 MACHADO, Diego Pereira. Sujeitos de direito internacional: Santa Sé e Vaticano. 2013. Disponível em: http://www.egov.ufsc.br/portal/conteudo/sujeitos-do-direito-internacional-santa-s\%C3\%A9-e-vaticano. Acesso em 09 de agosto de 2017.
} 
$S_{\text {Sorge }}{ }^{2}$ e encerrou a vida tentando (infrutiferamente) editar uma outra encíclica sobre a "unidade do gênero humano", em combate às perseguições raciais na Alemanha hitlerista ${ }^{3}$. Ele, porém, recebe severas e necessárias críticas por ter celebrado com Mussolini o Tratado de Latrão, silenciando sobre os abusos fascismo e, assim, contribuindo para a ascensão de tal regime totalitário na Itália". Por outro lado, alguns acusam o sucessor, Pio XII, de ser o "Papa de Hitler" ${ }^{\prime \prime}$, em razão de ter optado por uma posição de neutralidade frente à Segunda Guerra Mundial. Afirma-se, ainda, que ele teria sido o responsável por não dar seguimento aos planos de Pio $\mathrm{XI}$ a respeito da publicação de carta encíclica em sentido contrário à violência e intolerância racial operada contra os judeus. Diante de tais situações, e das demandas de Direitos Humanos que vêm surgindo desde o final da Segunda Guerra Mundial, é plenamente justificável indagar se, com as críticas históricas e políticas, os líderes máximos da Igreja vêm adotando postura firme em defesa da humanidade.

Metodologicamente, em primeiro lugar realizaremos consulta às fontes primárias - os discursos pontifícios. Na sequência, utilizaremos o método dedutivo para identificar o significado das manifestações a respeito da temática específica dos direitos humanos. Advirta-se o leitor que, para evitar poluição visual e o desnecessário aumento do número de páginas exclusivamente em razão do excesso de referências no curso do texto, o que é uma decorrência natural de recurso a fontes primárias, optou-se por fazer as indicações bibliográficas, especificamente em relação a trechos das manifestações, apenas ao final do artigo. Assim, havendo interesse de consultar o texto original dos pronunciamentos, há a devida informação no tópico "Referências", devendo a procura ser feita a partir do nome do Papa estudado em cada seção. Todas as demais citações, diretas ou indiretas, estão com as fontes indicadas nas notas de rodapé. Advirta-se também que foram utilizados os títulos honoríficos comumente atribuídos ao Chefe da Igreja Católica, sem que isso signifique qualquer juízo de valor, positivo ou negativo, sobre a Igreja como um todo, as pessoas que exerceram a função de pontífice ou sobre o cargo em si.

\section{PAULO VI}

Giovanni Montini, o Papa Paulo VI, foi líder da Igreja Católica entre 1963 e 1978. Foi o primeiro Pontífice a discursar diante da Organização das Nações Unidas, em Nova lorque, em 04 de outubro de 1965. À época, comemorava-se o vigésimo aniversário da ONU. Destaquese que o pronunciamento à ONU ocorreu às vésperas do encerramento do Concílio Vaticano

\footnotetext{
2 PAPA PIO XI. Carta Encíclica Mit Brennender Sorge. Cidade do Vaticano, 1937. Disponível em: http://w2.vatican.va/content/pius-xi/en/encyclicals/documents/hf_p-xi_enc_14031937_mit-brennendersorge.html. Acesso em 09 de agosto de 2017.

${ }^{3}$ EISNER, Peter. A última cruzada do Papa: como um jesuíta norte-americano auxiliou a campanha de Pio XI para travar Hitler. Tradução de Pedro Saraiva. Lisboa: Gradiva, 2016.

${ }^{4}$ KERTZER, David I. O papa e Mussolini: a conexão secreta entre Pio XI e a ascensão do fascismo na Europa. Tradução de Berilo Vargas. Rio de Janeiro: Intrínseca, 2017.

${ }^{5}$ CORNWELL, John. O Papa de Hitler - a história secreta de Pio XII. Tradução de A.B. Pinheiro de Lemos. Rio de Janeiro: Imago Ed., 2000.
} 
II, reunido entre outubro de 1962 e dezembro de 1965, com o propósito de "reconciliar a Igreja Católica com o mundo moderno" ${ }^{\prime}$.

Paulo VI, em primeiro lugar, destacou que, apesar de ser investido em uma minúscula e quase simbólica soberania temporal - a mínima necessária para exercer livremente sua missão espiritual, sem estar dependente de qualquer outra soberania -, o Papa é portador de uma mensagem - não apenas em seu nome próprio, mas também da família católica e dos cristãos que compartilham os sentimentos por ele manifestados - para toda a humanidade. Na sequência, o Chefe da Igreja Católica declarou ratificar moralmente e solenemente a Organização das Nações Unidas, reconhecendo que a ONU "representa o caminho obrigatório da civilização moderna e da paz mundial". Segundo ele, "os povos voltam-se para as Nações Unidas como para a última esperança da concórdia e da paz".

De acordo com o mencionado discurso pontifício, a ONU, ao propor a coexistência entre a pluralidade de nações, sanciona "o grande princípio de que as relações entre os povos devem ser reguladas pela razão, pela justiça, pelo direito e pela negociação, e não pela força, nem pela violência, nem pela guerra, assim como também não pelo medo ou pelo logro". 0 Papa ainda elogiou o acesso assegurado aos Estados que, então, apenas recentemente tinham atingido a independência e a liberdade nacionais. O Santo Padre pregou, ainda, a igualdade entre os membros da ONU, não devendo haver qualquer Estado acima do outro. Segundo ele, esta é a fórmula para evitar o orgulho e conservar a fraternidade entre os povos. O Papa conclamou "jamais uns contra os outros, nunca mais", citando ainda John Kennedy para destacar a necessidade de por fim à guerra e estabelecer que "a paz que deve guiar o destino dos povos e de toda a humanidade". Seguindo o raciocínio, o Pontífice asseverou que o primeiro caminho para a construção da paz é o desarmamento. De acordo com Paulo VI,

Se vós quereis ser irmãos, deixai cair as armas das vossas mãos. Não se pode amar com armas ofensivas nas mãos. As armas, sobretudo as terríveis armas que a ciência moderna vos deu, antes mesmo de causarem vítimas e ruínas, engendram maus sonhos, alimentam maus sentimentos, criam pesadelos, desconfianças, sombrias resoluções. Exigem enormes despesas. Detêm os projectos de solidariedade e de útil trabalho. Falseiam a psicologia dos povos.

O Chefe da Igreja argumentou que a missão da ONU - de garantir a segurança da vida internacional sem necessidade de recorrer às armas - poderá libertar os povos do pesadelo da guerra sempre iminente e, ainda, aliviar as despesas com armamentos. Esta última consequência ainda seria positiva no sentido de que as economias realizadas em relação a instrumentos bélicos poderiam ser direcionadas como auxílio aos países em desenvolvimento.

Para além da paz, Paulo VI conclamou os Estados a trabalhar uns para os outros: mais do que convivência, colaboração fraternal dos povos: "aqui instaura-se um sistema de solidariedade, que faz com que elevadas finalidades, no sentido da civilização, recebam o apoio unânime e ordenado de toda a família dos povos, para o bem de todos e de cada um". O Papa destacou, ainda, a defesa dos direitos e deveres fundamentais do homem, sua dignidade e

\footnotetext{
6 SOUZA, Ney de. Contexto e desenvolvimento histórico do Concílio Vaticano II. In: BOMBONATTO, V.; GONÇALVES, P.L. Concílio Vaticano II: análise e prospectivas. São Paulo: Paulinas, 2004. Disponível em: http://ciberteologia.paulinas.org.br/ciberteologia/wpcontent/uploads/2009/05/contexto_desenvolvimento.pdf. Acesso em 11 de janeiro de 2018.
} 
sua liberdade (em especial a religiosa). Defendeu, no mesmo sentido, a necessidade de alimentar os esfomeados, diminuir o analfabetismo e espalhar a cultura no mundo, bem como dar aos homens assistência sanitária apropriada e moderna. O Sumo Pontífice ressaltou o respeito à vida humana - que, sendo sagrada, não poderia ser objeto de ataque por ninguém. Segundo ele,

É na vossa Assembleia que o respeito da vida, mesmo no que se refere ao grande problema da natalidade, deve encontrar a sua mais alta profissão e a sua mais racional defesa. A vossa tarefa é agir de modo que o pão seja abundante à mesa da humanidade, e não favorecer um «controle» artificial dos nascimentos, que seria irracional, com a finalidade de diminuir o número dos convivas ao banquete da vida.

Por fim, Paulo VI concluiu fazendo um apelo à consciência moral do homem, para que os instrumentos cada vez mais poderosos, decorrentes do progresso e da ciência, fossem utilizados para as mais elevadas conquistas, e não para a ruína da humanidade.

De todo o exposto, percebe-se que o discurso pontifício deu especial destaque à questão da paz, o que é plenamente justificável. À época, completavam-se os 20 anos do fim da Segunda Guerra Mundial. Além disso, poucos meses antes do pronunciamento papal, naquele mesmo ano, teve início a famigerada Guerra do Vietnã. Do mesmo modo, o mundo ainda vivia a Guerra Fria, com o risco de uma catástrofe nuclear - de onde se depreende compreensível o apelo de Paulo VI ao desarmamento.

Por outro lado, nota-se a relevância conferida pelo Chefe da Igreja Católica à questão pertinente à defesa da vida, à natalidade e ao controle dos nascimentos. Trata-se de tema muito caro ao pontificado de Giovanni Montini. Poucos anos depois do discurso em questão, Paulo VI publicou sua Carta Encíclica Humanae Vitae ${ }^{7}$, no qual condenou o aborto, a esterilização (perpétua ou temporária) e quaisquer atos sexuais tornados intencionalmente infecundos (com o uso da camisinha ou da pílula anticoncepcional, por exemplo). Nesse ponto específico, o caminho percorrido pela ONU e pela construção dos direitos humanos acabou se afastando do posicionamento papal. Com efeito, na década de 1990, nas Conferências Internacionais do Cairo e de Copenhague, foram consagrados - com resistências da Santa Sé, ressaltese - os direitos sexuais e reprodutivos, assegurando às pessoas saúde reprodutiva, autonomia no controle da fertilidade e prevenção de doenças sexualmente transmissíveis ${ }^{8}$.

Conclusivamente, merece distinção o comentário pontifício a respeito da liberdade religiosa. Poucas semanas depois, em dezembro de 1965, o Papa aprovou e publicou a Declaração Dignitatis Humanae, do Concílio Vaticano II, a respeito da liberdade religiosa. Nela, a Igreja reconheceu direito de toda pessoa professar livremente a religião, em particular e em público. $\mathrm{O}$ referido documento guarda total coerência com as palavras proferidas à Assembleia das Nações Unidas.

\footnotetext{
${ }^{7}$ PAPA PAULO VI. Discurso do Papa Paulo VI na sede da ONU. Nova lorque, 4 de outubro de 1965. Disponível em: http://w2.vatican.va/content/paul-vi/pt/speeches/1965/documents/hf_p-vi_spe_19651004_unitednations.html. Acesso em 31 de julho de 2017.

${ }^{8}$ GUARNIERI, Tathiana Haddad. Os direitos das mulheres no contexto internacional - da criação da ONU (1945) à Conferência de Beijing (1995). Revista Eletrônica da Faculdade Metodista Granbery, 2010. Disponível em: http://re.granbery.edu.br/artigos/MzUx.pdf. Acesso em 11 de janeiro de 2018.
} 


\title{
2 JOÃO PAULO II
}

O Papa João Paulo II, nascido Karol Józef Wojtyła, foi Pontífice entre 1978 e 2005. Durante tal período, pronunciou-se à Organização das Nações Unidas em duas oportunidades: primeiramente em 1979 e, depois, em 1995. Como forma a melhor esquematizar a presente investigação, cada discurso será analisado separadamente.

\subsection{Primeiro discurso: outubro de 1979}

João Paulo II, após os cumprimentos e agradecimentos às autoridades, iniciou seu discurso da mesma forma que Paulo VI fizera: ressaltando a soberania da Santa Sé e a necessidade de o Papado exercitar a sua missão com plena liberdade e de forma independente de outras soberanias. Destacou, igualmente, a importância da ONU na busca pela pacífica convivência e colaboração entre as nações e na prevenção da guerra, da divisão e da recíproca destruição da humanidade.

O Sumo Pontífice fez ampla reverência à universalidade da dignidade humana. Do mesmo modo, estabeleceu que toda atividade política, além de prover do homem e se exercitar mediante o homem, deve ser para o homem; se se tornar fim em si mesma, perde sua razão de ser e pode cair em contradição com a própria humanidade. João Paulo II ressaltou a relevância da Carta das Nações Unidas e da Declaração Universal dos Direitos do Homem (DUDH) enquanto defesas do valor universal da humanidade. Asseverou, assim, ser

\begin{abstract}
necessário medir o progresso da humanidade não somente pelo progresso da ciência e da técnica - do qual se evidencia toda a singularidade do homem em confronto com a natureza - mas simultaneamente pelo primado dos valores espirituais e pelo progresso da vida moral.
\end{abstract}

Relembrando os horrores da Segunda Guerra Mundial, em especial dos campos de concentração - notadamente Auschwitz, na sua Polônia natal-, o Papa aduziu que de tais dolorosas experiências surgiu a DUDH. Esta Declaração, para o Pontífice, "deve permanecer na Organização das Nações Unidas o valor de base, com o qual se há-de confrontar e à qual vá haurir inspiração constante a consciência dos seus Membros". O Chefe da Igreja ressaltou que a Declaração Universal dos Direitos do Homem, juntamente com outros instrumentos jurídicos nacionais e internacionais, faz parte de um movimento progressivo e contínuo na construção de uma consciência geral da dignidade do homem. Citando vários direitos humanos, Wojtyła destacou que

O conjunto dos direitos do homem corresponde à substância da dignidade do ser humano, entendido integralmente, e não reduzido a uma só dimensão; tais direitos referem-se à satisfação das necessidades essenciais do homem, ao exercício das suas liberdades e às suas relações com as outras pessoas; mas eles referem-se sempre e em toda a parte ao homem, à sua plena dimensão humana. 
João Paulo II, rememorando o discurso de Paulo VI naquela tribuna, 14 anos antes, declarou que "a Igreja Católica em todas as partes da terra proclama uma mensagem de paz, reza pela paz e educa para a paz". Nesse sentido, manifestou seu desejo de, assim como o antecessor, ser um "infatigável servidor da causa da paz". Do mesmo modo, o Papa agradeceu a Deus pela resolução da tensão que, no ano anterior (1978), ameaçava a Argentina e o Chile. Por outro lado, o Pontífice demonstrou sua inquietude com as crises do Oriente Médio. Saudando as diligências e iniciativas para a composição dos conflitos na região, asseverou que a paz ali deveria ser alcançada com fundamento "no equitativo reconhecimento dos direitos de todos, não pode deixar de incluir a consideração e a justa solução do problema palestinense".

O Santo Padre também revelou consternação com "o desenvolver-se dos armamentos, que ultrapassam meios e dimensões de luta e de destruição jamais conhecidos até agora". Segundo ele, a corrida armamentista representava grave risco sobre a vida da humanidade. Nesse sentido, criticou a resistência às propostas concretas e efetivas de desarmamento, afirmando que "com a vontade de paz declarada por todos e pela maior parte desejada, coexiste, talvez escondido, talvez hipotético, mas real, o seu contrário e a sua negação". Seu tom de desaprovação foi deveras duro:

Os contínuos preparativos para a guerra, de que é prova a produção das armas cada vez em maior número, mais potentes e mais insidiosas, em vários países, estão a testemunhar que se quer estar prestes para a guerra, e estar prestes quer dizer estar em condições de provocá-la e quer dizer também correr o risco de quer em qualquer momento; em qualquer parte e de qualquer maneira, alguém possa pôr em movimento o terrível mecanismo de destruição geral.

João Paulo II defendeu que um dos caminhos para liquidar as possibilidades de guerra e construir um futuro pacífico para o planeta consiste no combate às violações aos inalienáveis direitos do homem. Argumentou que a gênese dos conflitos está na injustiça e, por isso,

\footnotetext{
Todas as análises, necessariamente, devem partir das mesmas premissas; ou seja, que todo o ser humano possui uma dignidade que - não obstante a pessoa existir sempre num contexto social e histórico concreto - não poderá jamais ser diminuída, ferida ou destruída; mas que, pelo contrário, deve ser respeitada e protegida se se quer realmente construir a paz.
}

Do mesmo modo, o Pontífice ressaltou que são igualmente perigosas para a paz, por atingirem o homem em sua integridade, as ameaças aos direitos humanos tanto no âmbito dos bens materiais como no âmbito dos bens espirituais. Ressalvando, bem que se diga, o primado destes bens em relação àqueles, chamou a atenção para os riscos de conflitos decorrentes da desigualdade. Em razão disto, o Papa sustentou a eliminação ao máximo das várias formas de exploração do homem e a garantia, a este mesmo homem, mediante o trabalho, não somente de uma "justa distribuição dos bens materiais indispensáveis, mas também uma participação correspondente à sua dignidade em todo o processo de produção e na própria vida social que, em volta deste processo, se vai formando". Nesse sentido, criticou "o abismo entre a minoria dos excessivamente ricos e a multidão dos que sofrem a miséria", asseverando que tal disparidade somente será banida com a cooperação coordenada de todas as nações. 
João Paulo II chamou a atenção, ainda, para as "diversas formas de injustiça no campo do espírito", referindo-se às violações relativas à liberdade religiosa, de pensamento, de expressão e de consciência. Destacou a importância da igualdade de direitos e condenando a "discriminação por motivos de origem, raça, sexo, nacionalidade, confissão, convicções políticas e semelhantes". No tocante à liberdade de religião, além de se referir à já mencionada Declaração Dignitatis Humanae, defendeu que tal direito deve resguardar, igualmente, as instituições que, por sua natureza, servem a vida religiosa.

Da análise do discurso ora comentado, depreende-se que o Pontífice, assim como seu antecessor, preocupou-se detidamente na pregação em favor da paz. O momento assim exigia. Apesar de, por questões econômicas, a década de 1970 ter sido marcada por uma détente (relaxamento nas hostilidades) entre União Soviética e Estados Unidos, em 1979 já se verificava um recrudescimento das tensões ${ }^{9}$. Não por outra razão, iniciou-se a Guerra entre URSS e Afeganistão em dezembro daquele ano, poucas semanas após a reunião da Assembleia Geral da ONU. Ao se referir à tensão entre Chile e Argentina, João Paulo II tratava do conflito a respeito do Canal de Beagle. A disputa pelo mencionado Canal entre tais países chegou a um ponto crítico em 1978, com graves possibilidades de beligerância na região. A Santa Sé atuou ativamente na questão, buscando um trabalho de mediação para excluir o uso da força. 0 Tratado entre chilenos e argentinos, finalmente assinado em 1984, é considerado um sucesso do Papa, na medida em que pacificamente pôs termo à controvérsia numa região considerada conturbada ${ }^{10}$. No tocante ao Oriente Médio, o Papa mostrou-se sensível em especial à Guerra Civil Libanesa e à questão da Palestina. João Paulo II conclamou a humanidade pela paz no Oriente Médio até o fim de sua vida, em abril de 2005 quase 30 anos após o multimencionado pronunciamento à $\mathrm{ONU}^{11}$.

Destaque-se, por fim, que, assim como Paulo VI, João Paulo II ratificou moral e espiritualmente a Declaração Universal de Direitos Humanos. O significado disso é profundo, pois significa que a Igreja, na pessoa do seu líder mundial, chancela (e, portanto, compromete-se a proteger) os direitos inalienáveis de todas as pessoas do planeta.

\footnotetext{
${ }^{9}$ MUNHOZ, Sidnei José; ROLLO, José Henrique. DÉTENTE E DÉTENTES NA ÉPOCA DA GUERRA FRIA (DÉCADAS DE 1960 E 1970). Esboços - Revista do Programa de Pós-Graduação em História da UFSC, Florianópolis, v. 21, n. 32, p. 138-158, $\quad$ out. $2015 . \quad$ ISSN 2175-7976. Disponível em: https://periodicos.ufsc.br/index.php/esbocos/article/view/2175-7976.2014v21n32p138. Acesso em: 12 de janeiro de 2018.

${ }^{10}$ PORTILHO, Ana Cláudia. O ator santa sé na política internacional moderna.. In: $3^{\circ}$ ENCONTRO NACIONAL ABRI 2001, 3., 2011, São Paulo. Proceedings online... Assosciação Brasileira de Relações Internacionais Instituto de Relações Internacionais - USP, Available from: http://www.proceedings.scielo.br/scielo.php?script=sci_arttext\&pid=MSC0000000122011000100013\&lng=en \&nrm=abn. Acesso em 12 de Janeiro de 2018.

11 Vejam-se exemplos em: http://www.bbc.com/portuguese/noticias/2001/010802_arafatpapa2.shtml (2001); https://www.correiodobrasil.com.br/papa-exorta-o-mundo-a-evitar-guerra-no-oriente-medio/ http://www.agencia.ecclesia.pt/noticias/vaticano/joao-paulo-ii-denuncia-violencia-inaceitavel-no-orientemedio/ (2004).
} 


\subsection{Segundo discurso: outubro de 1995}

Dezesseis anos após sua primeira proclamação à Organização das Nações Unidas, João Paulo II compareceu novamente à tribuna da Assembleia Geral para discursar. À época, comemoravam-se os 50 anos de fundação da ONU.

O Pontífice, em primeiro lugar, chamou a atenção para o crescimento global da busca pela liberdade. Sublinhou que, em todo o planeta, homens e mulheres - ainda quando ameaçados pela violência - vêm clamando por um lugar na vida social, política e econômica compatível com sua dignidade enquanto seres humanos livres. Recordando seu discurso anterior à ONU, o Chefe da Igreja afirmou que a busca por liberdade é baseada nos direitos universais que cada pessoa desfruta em decorrência no simples fato de sua humanidade - cujo fundamento último seria, para ele, uma lei moral universal. Rememorou, ainda, que foram as violações a tais direitos que levaram à formulação da DUDH - em sua opinião, uma das maiores expressões da consciência humana.

De acordo com o Papa, a mencionada lei moral universal é a gramática necessária para o diálogo entre indivíduos e povos, bem como para substituir o século XX, marcado pela coerção violenta, por um século XXI destacado pela persuasão. Por essa razão, demonstrou preocupação com as pessoas negando que a natureza humana e, portanto, os direitos humanos são compartilhados por todos. O Pontífice, reconhecendo não haver um único modelo de organizar a política e a economia, afirmou que existe uma diferença entre pluralismo e a negação da universalidade da natureza humana.

João Paulo II, referindo-se especificamente aos movimentos ocorridos na Europa (Central e Oriental) no final da década de 1980, conclamou que a busca pela liberdade não pode ser suprimida; ela surge do reconhecimento da dignidade e do valor da pessoa humana, não podendo deixar de ser acompanhada de um compromisso em favor do ser humano. Assim, criticou o totalitarismo moderno, classificando-o como um ataque à dignidade humana que chega a negar o inalienável valor de cada vida. Do mesmo modo, Wojtyła defendeu que as revoluções europeias de 1989, não violentas, tiveram como fator decisivo a solidariedade social contra os regimes sustentados pelo poder da propaganda e do terror. Em sentido semeIhante, asseverou que há uma conexão entre os movimentos por libertação e os compromissos morais inscritos na Carta das Nações Unidas, devendo a ONU ser uma luz no combate à tirania, mostrando o caminho para a liberdade, paz e solidariedade.

Ainda nesse sentido, o polonês destacou que a busca por liberdade é igualmente partilhada pelas nações. Assim, argumentou que a ONU nasceu da convicção de que as doutrinas que motivaram a Segunda Guerra Mundial - que ensinavam a inferioridade de determinadas nações e culturas - eram antitéticas à paz. Do mesmo modo, a Carta das Nações Unidas trouxe implícito um compromisso moral de defender cada povo e cultura contra injustiças e agressões violentas. Por essa razão, denunciou o fato de que, infelizmente, mesmo após o fim do referido conflito global, os direitos das nações continuaram a ser violados, em especial no contexto da Guerra Fria. O Papa defendeu uma ponderação acerca das questões sobre justiça e liberdade no mundo, em especial porque não houve um entendimento internacional, semeIhante à DUDH, adequadamente endereçado aos direitos das nações. Estes seriam nada mais do que direitos humanos alçados ao nível específico da vida comunitária. 
Para João Paulo II, um pressuposto dos direitos das nações é o direito de existir: ninguém (pessoa, Estado ou organização internacional) pode afirmar que uma nação é indigna de existir. Argumentou, todavia, que isso não se confunde com o direito a ser um Estado soberano, na medida em que várias formas de agregação jurídica entre diferentes nações seriam possíveis (desde que pautadas pela liberdade e pela autodeterminação dos envolvidos). Do mesmo modo, o Santo Padre argumentou que toda nação teria o direito de moldar sua vida de acordo com suas próprias tradições - excetuando-se, naturalmente, as violações aos direitos humanos básicos, em particular a opressão das minorias.

Sobre o problema das nacionalidades, ainda, referiu-se à questão da mobilidade (decorrente, entre outras coisas, da globalização e das migrações) e à explosão dos problemas acerca de consciência étnica e cultural. O Pontífice sublinhou se tratar de matéria a ser examinada sob as óticas da Antropologia, da Ética e do Direito.

Por outro lado, acentuou que as nações não têm apenas direitos, mas também deveres (para com as demais e para com a humanidade como um todo), em especial a busca por viver em um espírito de paz, respeito e solidariedade. Assim, o equilíbrio entre o exercício dos direitos e a prática dos deveres promove uma "troca de presentes" que fortalece a unidade da espécie humana.

O Papa, então, passou a refletir sobre a questão do respeito às diferenças, conclamando o mundo a aprender a viver com a diversidade e lamentando os episódios ocorridos nos Bálcãs e na África Central. Destacou que o medo da diferença, ampliado por questões históricas e exacerbado pela manipulação de pessoas inescrupulosas, pode ensejar a negação da humanidade "do outro" (do diferente), o que resulta em um ciclo de violência do qual ninguém é poupado - nem mesmo as crianças. Relembrou, nesse sentido, o pesadelo de violência e terror criado, no passado, pela negação dos direitos "do outro" expressada em manifestações extremas de nacionalismo.

O Pontífice novamente defendeu a salvaguarda do direito fundamental à liberdade religiosa e de consciência, enquanto pedras angulares da estrutura dos direitos humanos e fundações de toda sociedade verdadeiramente livre. Do mesmo modo, asseverou que a liberdade é a medida da grandeza e dignidade humanas. Para o Papa, porém, ela deve ser exercida de forma responsável, pessoal e socialmente. Nesse sentido, criticou as doutrinas utilitaristas (que definem a moralidade não em termos do que é bom, mas do que é vantajoso). Para ele, o utilitarismo constantemente tem consequências políticas devastadoras: por exemplo, a subjugação de uma nação menor ou mais fraca é justificada por corresponder a um interesse nacional maior. Do mesmo modo, em uma perspectiva econômica, tal doutrina fundamenta a exploração e manipulação de países mais fracos pelos mais fortes. De acordo com o Pontífice, ambos os fenômenos ora mencionados se verificam nas relações entre o "Norte" e o "Sul". Defendeu que os países desenvolvidos renunciem ao estrito utilitarismo e aprimorem abordagens inspiradas por mais justiça e solidariedade, no sentido de permitir que os países em desenvolvimento possam oferecer às pessoas maiores recursos, assistência e, consequentemente, mais respeito pelos direitos humanos (o que passa, segundo João Paulo II, pela substituição dos governos autoritários e corruptos pelos democráticos).

O Papa concluiu seu discurso afirmando que as pessoas devem aprender a não ter medo, redescobrindo um espírito de esperança e confiança. Aduziu que esperança e confiança não são matérias estranhas ao escopo da ONU. Para ele, a resposta ao medo consiste na cons- 
trução de uma sociedade do amor, fundada nos valores universais da paz, solidariedade, justiça e liberdade. Assim, as lágrimas do século XX servirão para preparar o solo para uma nova primavera do espírito humano.

Da análise do discurso pontifício, percebe-se que João Paulo II focou suas palavras nas questões do direito (individual e nacional) à liberdade, da proteção às minorias e do combate à desigualdade opressora. Chama a atenção, evidentemente, o destaque feito pelo Papa aos movimentos de libertação na Europa no final da década de 1980. Conclui-se facilmente que se referia em especial aos eventos ocorridos na sua Polônia natal, onde se deu o primeiro passo para a derrocada do comunismo no Leste Europeu, com a vitória da oposição ao regime comunista polonês nas eleições realizadas em 1989. Não se trata de uma referência ao acaso: João Paulo II foi uma figura estratégica na resistência ao comunismo, em especial com suas frequentes viagens ao seu país de origem. Lá, apoiou o famoso sindicato Solidarność, de Lech Wałęsa, tendo também protestado contra as ameaças de invasão da Polônia pelas tropas soviéticas ${ }^{12}$.

A questão balcânica, suscitada pelo Pontífice ao tratar do respeito às diferenças, refere-se à explosão de conflitos na região nos anos que antecederam o multimencionado discurso. Na década de 1990, a península foi marcada por tensões: o início da fragmentação da lugoslávia, com a independência da Croácia e da Eslovênia; e a guerra da Bósnia, iniciada em 1992. Posteriormente, haveria ainda outros lamentáveis episódios nos Bálcãs, como a Guerra do Kosovo, entre 1998 e 1999, o que demonstra não terem sido ouvidas as intervenções pontifícias. O Papa também mencionou episódios ocorridos na África. Referia-se aos intermináveis e sangrentos conflitos no continente africano, do qual pode ser destacado o genocídio perpetrado em Ruanda, pelos hutus contra os tutsis, na esteira da guerra civil verificada naquele país.

Por outro lado, falou com conhecimento de causa acerca de pesadelos de violência e terror decorrentes do nacionalismo e do medo das diferenças. Apesar de não ser judeu, e, portanto, escapado do genocídio deste povo na Segunda Guerra Mundial, Wojtyła nasceu na Polônia. Os poloneses - mesmo os não semitas - foram, também, severamente perseguidos pelos nazistas (que os consideravam untermenschen, sub-humanos). João Paulo II, que tinha 19 anos no eclodir do conflito, experimentou de perto os dissabores do jugo alemão.

Ao tocar na questão da desigualdade social (relativa a pessoas, mas também pertinente às relações entre países), Wojtyła revelou a preocupação demonstrada, durante todo o seu pontificado, com os mais pobres e necessitados. Percebe-se, também, que mostra a sensibilidade da Igreja Católica a esse respeito, apesar das constantes e tradicionais críticas sobre sua ideologia legitimadora dos interesses dos mais ricos e poderosos.

\section{BENTO XVI}

Joseph Ratzinger, o Papa Bento XVI, foi o líder da Igreja Católica entre 2005 e 2013. Seu pontificado terminou não por sua morte, mas em razão de sua renúncia. Em 18 de abril

12 AZEVEDO, Dermi. Desafios estratégicos da Igreja Católica. Lua Nova, n.60, 2003. Disponível em: http://www.scielo.br/pdf/\%0D/ln/n60/a04n60.pdf. Acesso em: 14 de janeiro de 2018, p. 72. 
de 2008, ele compareceu à sede da ONU, onde discursou. Comemorava-se, então, o sexagésimo aniversário da Declaração Universal dos Direitos do Homem.

O Papa iniciou seu pronunciamento destacando a importância da Organização das Nações Unidas no sentido de dar vida a objetivos universais que representam uma parte fundamental do bem comum da família humana. Sublinhou, assim, os princípios fundadores da ONU, notadamente o desejo da paz, a busca da justiça, o respeito da dignidade da pessoa humana, a cooperação humanitária e a assistência; todos estes, aduziu, "expressam as justas aspirações do espírito humano e constituem os ideais que deveriam estar subjacentes às relações internacionais".

O Pontífice argumentou ser necessária uma atuação conjunta, rápida, de boa-fé, pautada no respeito à lei e na promoção da solidariedade com as regiões mais débeis do planeta. Deu especial relevo aos "países da África e de outras partes do mundo que permanecem na margem de um autêntico progresso integral, e por isso correm o risco de experimentar apenas os efeitos negativos da globalização". De acordo com Ratzinger, no que diz respeito às relações internacionais, as regras e estruturas ordenadas para o bem comum não limitam a liberdade humana, ao contrário, promovem-na "quando proíbem comportamentos e actos que vão contra o bem comum, obstam à sua prática efectiva e por isso comprometem a dignidade de cada pessoa humana". Nesse sentido, asseverou que há uma correlação entre direitos e deveres e que cada pessoa deve assumir a responsabilidade das próprias ações.

O Chefe da Igreja, então, iniciou uma reflexão sobre os empregos dos resultados das descobertas científicas e tecnológicas. Mesmo reconhecendo que muitas destas geram enormes benefícios para a humanidade, argumentou que alguns aspectos de tal aplicação representam "uma clara violação da ordem da criação, até ao ponto em que não só é contrastado o carácter sagrado da vida, mas a própria pessoa humana e a família são privadas da sua identidade natural". Do mesmo modo, pregou o uso racional da tecnologia e da ciência em função da preservação do ambiente e da proteção às várias formas de vida. Defendeu, assim, a adoção de "um método científico que seja verdadeiramente respeitador dos imperativos éticos".

Bento XVI ressaltou o "princípio da responsabilidade de proteger", argumentando que, apesar de se tratar de definido há pouco tempo, já se encontrava implícito nas origens das Nações Unidas. Segundo ele,

Cada Estado tem o dever primário de proteger a própria população de violações graves e contínuas dos direitos humanos, assim como das consequências das crises humanitárias, provocadas quer pela natureza quer pelo homem. Se os Estados não são capazes de garantir semelhante protecção, a comunidade internacional deve intervir com os meios jurídicos previstos pela Carta das Nações Unidas e por outros instrumentos internacionais. A aç̧ão da comunidade internacional e das suas instituições, suposto o respeito dos princípios que estão na base da ordem internacional, nunca deve ser interpretada como uma imposição indesejada e uma limitação de soberania. Ao contrário, é a indiferença ou a falta de intervenção que causam danos reais.

O discurso pontifício passou, a partir daí, a tratar da Declaração Universal dos Direitos do Homem (DUDH), que, conforme já mencionado, à época completava seus 60 anos. O Papa asseverou que "os direitos humanos estão cada vez mais presentes como linguagem comum e substracto ético das relações internacionais" e que "a universalidade, a indivisibilidade e a interdependência dos direitos humanos servem todas de garantias para a salvaguarda da dig- 
nidade humana". Nesse sentido, condenou uma perspectiva relativista, "segundo a qual o significado e a interpretação dos direitos poderiam variar e a sua universalidade seria negada em nome de contextos culturais, políticos, sociais e até religiosos diferentes".

Ratzinger argumentou que o respeito aos direitos humanos e às garantias deles derivados são medidas que servem para analisar as relações entre justiça e injustiça, desenvolvimento e pobreza, segurança e conflito. Neste sentido, defendeu que "a promoção dos direitos humanos permanece a estratégia mais eficaz para eliminar as desigualdades entre Países e grupos sociais, assim como para um aumento da segurança". Em sua opinião, a pessoa que sofre privações e maiores violações à sua dignidade é presa fácil do chamado à violência, podendo ela mesma se tornar violadoras da paz.

O Papa criticou as "pressões para reinterpretar os fundamentos da Declaração e de comprometer a sua unidade íntima, de modo a facilitar um afastamento da protecção da dignidade humana para satisfazer simples interesses, muitas vezes interesses particulares". Segundo ele, a DUDH "não pode ser aplicada por partes destacadas, segundo tendências ou opções selectivas que simplesmente correm o risco de contradizer a unidade da pessoa humana e, portanto, a indivisibilidade dos direitos humanos".

O Pontífice alertou para não se tratar dos direitos humanos como resultado exclusivo de resoluções legislativas ou de decisões de quem se encontra no poder. Fundamentou tal comentário no fato de que, "quando são apresentados simplesmente em termos de legalidade, os direitos correm o risco de se tornarem débeis proposições separadas da dimensão ética e racional, que é o seu fundamento e finalidade". Aduziu, então, que "os direitos humanos devem ser respeitados como expressão de justiça e não simplesmente porque podem ser feitos respeitar mediante a vontade dos legisladores".

Bento XVI destacou que, "enquanto a história procede, surgem novas situações e tenta-se relacioná-las com novos direitos". Para ele, por essa razão, o discernimento (enquanto capacidade de distinguir o bem e o mal) é uma virtude indispensável para enfrentar o tema dos direitos, na medida em que demonstra as possíveis consequências negativas de se confiar exclusivamente aos Estados, individualmente, a responsabilidade última de atender às aspirações das pessoas, comunidades e povos inteiros. Sustentou, ainda, que "o reconhecimento do valor transcendente de cada homem e mulher favorece a conversão do coração, que leva depois a um compromisso de resistir à violência, ao terrorismo e à guerra e de promover a justiça e a paz".

Acerca do diálogo inter-religioso, o Chefe da Igreja Católica considerou-o como "meio mediante o qual as várias componentes da sociedade podem articular o próprio ponto de vista e construir o consenso em volta da verdade relativa aos valores e objectivos particulares". Isso porque compete às religiões "propor uma visão da fé não em termos de intolerância, de discriminação e de conflito, mas em termos de respeito total da verdade, da coexistência, dos direitos e da reconciliação". Bento XVI defendeu a liberdade religiosa, que, em sua concepção, deve ser compreendida "como expressão de uma dimensão que é ao mesmo tempo individual e comunitária, uma visão que manifesta a unidade da pessoa, mesmo distinguindo claramente entre a dimensão de cidadão e a de crente". Em tal direito, incluem-se diversas suas dimensões, em especial as liberdades de ritual, de culto, de educação, de difusão de informações, de professar e de escolher uma religião. Asseverou, assim, ser "inconcebível que crentes devam suprimir uma parte de si mesmos a sua fé para serem cidadãos activos; nunca deveria ser necessário renegar Deus para poder gozar dos próprios direitos". Destacando os possíveis 
conflitos com as ideologias seculares prevalecentes ou com as posições de uma maioria religiosa dominante, e criticando a "recusa de reconhecer a contribuição à sociedade que está radicada na dimensão religiosa", o Pontífice concluiu que "não se pode limitar a plena garantia da liberdade religiosa à prática livre de culto; ao contrário, deve ser tida em justa consideração a dimensão pública da religião e portanto a possibilidade dos crentes desempenharem a sua parte na construção da ordem social".

O Papa encerrou sua intervenção rememorando o papel da Santa Sé nas assembleias das Nações e defendendo que os direitos humanos

estão baseados e modelados sobre a natureza transcendente da pessoa, que permite a homens e mulheres percorrerem o seu caminho de fé e a sua busca de Deus neste mundo. O reconhecimento desta dimensão deve ser fortalecido se quisermos apoiar a esperança da humanidade num mundo melhor, e se quisermos criar as condições para a paz, o desenvolvimento, a cooperação e a garantia dos direitos das gerações futuras.

Percebe-se, também, que Bento XVI demonstrou preocupação com a preservação do ambiente. Na ONU, ele não poderia ter deixado de abordar um tema que foi pauta de todo o seu papado ${ }^{13}$ e que Ihe continuou sendo caro, mesmo após a sua abdicação. Foi, por exemplo, um grande defensor da tecnologia verde, tendo inclusive adquirido o primeiro Papamóvel híbrido ${ }^{14}$. Nos anos em que exerceu o pontificado, Ratzinger tratou diversas vezes sobre a ecologia, tendo notadamente abordado o tema de forma aprofundada em sua última Carta Encíclica, Caritas in Veritate, de 2009. Nesta, entre outras afirmações, sustentou que "a natureza é expressão de um desígnio de amor e de verdade"; ela "precede-nos, tendo-nos sido dada por Deus como ambiente de vida". Asseverou ainda que "os deveres que temos para com o ambiente estão ligados com os deveres que temos para com a pessoa considerada em si mesma e em relação com os outros" ${ }^{15}$.

O "princípio da responsabilidade de proteger", mencionado pelo Pontífice, surgiu devido a questões acerca da legalidade e legitimidade das intervenções humanitárias. A referida doutrina, trabalhada no âmbito das Nações Unidas desde o início dos anos 2000, "propõe alterações doutrinárias, práticas e étnicas no tratamento das intervenções humanitárias pelo Direito Internacional, trazendo uma abordagem mais holística com a proposta de responsabilidades de reagir, prevenir e reconstruir" (JUBILUT, 2008). A primeira alteração se deu na concepção de soberania: de direito absoluto para limitado pela responsabilidade. Ademais, o direito de ingerência converteu-se na chamada "responsabilidade de proteger" - o que foca

13 A título de exemplo, vejam-se as seguintes reportagens, respectivamente de 2008, 2009 e 2011 : https://oglobo.globo.com/mundo/no-dia-mundial-da-paz-papa-bento-xvi-fala-sobre-conflitos-meio-ambiente3854252; https://noticias.cancaonova.com/mundo/papa-bento-xvi-fala-sobre-importancia-de-cuidar-do-meioambiente/; e https://noticias.terra.com.br/bento-xvi-reafirma-importancia-do-meio-ambiente-aosbrasileiros,0a583af1594fa310VgnCLD200000bbcceb0aRCRD.html.

14 Papamóvel é o automóvel no qual o Sumo Pontífice costuma fazer suas aparições públicas. A respeito do primeiro modelo híbrido, podem ser adquiridas maiores informações em: https://exame.abril.com.br/mundo/bento-xvi-vai-ganhar-um-papamovel-hibrido/ .

${ }^{15}$ PAPA BENTO XVI. Carta Encíclica Caritas in veritate sobre o desenvolvimento humano integral na caridade e na verdade. 2009. Disponível em: http://w2.vatican.va/content/benedict-xvi/pt/encyclicals/documents/hf_benxvi_enc_20090629_caritas-in-veritate.html. Acesso em 15 de janeiro de 2018. 
mais nos interesses dos beneficiários, destaca também as ações preventivas e não contraria a regra geral da ONU de não-intervenção.

Percebe-se também que o Papa criticou uma visão juspositivista dos direitos humanos. Negou que estes devem ser protegidos exclusivamente em razão de terem sido reconhecidos e positivados pelo aparato jurídico-legislativo de um Estado, mas verdadeiramente porque são fundamentados na dignidade de cada ser humano.

O Chefe da Igreja, ao defender a liberdade religiosa, seguiu o mesmo caminho trilhado por Paulo VI (em 1965) e João Paulo II (em 1979 e 1995) quando discursaram à Assembleia Geral da Organização das Nações Unidas. Como proferidas pelo líder de uma das grandes religiões monoteístas do mundo, tais palavras têm duas dimensões: por um lado, são proferidas em socorro dos cristãos que sofrem perseguições; por outra perspectiva, servem como alerta para que a família cristã não seja sujeito ativo de tais opressões. Ao defender a dimensão pública da liberdade religiosa, Bento XVI criticou a exclusão dos segmentos religiosos do diálogo para elaboração das pautas e políticas desenvolvidas no plano interno dos Estados (em suas palavras, na construção da ordem social). Depreende-se, assim, que intercedeu para que "Estado laico" não se confunda com Estado no qual as religiões não têm voz. Trata-se de escopo interessante no conteúdo de tal direito.

\section{FRANCISCO}

Francisco, nascido Jorge Mario Bergoglio, é Papa desde 2013, eleito após a renúncia de Bento XVI. Esteve presente à sede da Organização das Nações Unidas em 25 de setembro de 2015, época em que se celebrava o septuagésimo aniversário da ONU.

Após suas saudações às autoridades e aos cidadãos de todo o mundo ali representados, o Papa relembrou seus antecessores que por ali passaram para reforçar o apreço pela Organização das Nações Unidas e a importância e esperança conferidas pela Igreja a tal instituição. Ao relembrar dos sucessos conquistados nos 70 anos da ONU, o Pontífice destacou, entre outros, "a construção da normativa internacional dos direitos humanos, o aperfeiçoamento do direito humanitário, a solução de muitos conflitos e operações de paz e reconciliação". Para ele, "cada um destes avanços políticos, jurídicos e técnicos representa um percurso de concretização do ideal da fraternidade humana e um meio para a sua maior realização".

Francisco sustentou que se faz necessário "conceder a todos os países, sem excepção, uma participação e uma incidência reais e equitativas nas decisões", em especial nos órgãos com capacidade executiva real como os organismos financeiros e os mecanismos de enfrentamento das crises econômicas. Dessa forma, limita-se "qualquer espécie de abuso ou usura especialmente sobre países em vias de desenvolvimento". Afirmou ainda que

Os Organismos Financeiros Internacionais devem velar pelo desenvolvimento sustentável dos países, evitando uma sujeição sufocante desses países a sistemas de crédito que, longe de promover o progresso, submetem as populações a mecanismos de maior pobreza, exclusão e dependência. 
O Papa centrou o seu discurso na defesa de dois pontos: a proteção do meio ambiente e o combate à exclusão social. Criticou, assim, especialmente o mau exercício do poder, na medida em que as relações políticas e econômicas preponderantes transformam os referidos temas em partes frágeis da realidade.

Inicialmente, Francisco afirmou a existência de um "direito ao ambiente", fundamentado em duas razões. A um, porque o homem é uma porção do ambiente, vivendo em comunhão com ele. Existem, portanto, limites éticos que devem ser reconhecidos e respeitados, porquanto "qualquer dano ao meio ambiente é um dano à humanidade". A dois, pois "cada uma das criaturas, especialmente seres vivos, possui em si mesma um valor de existência, de vida, de beleza e de interdependência com outras criaturas".

Por outro lado, o Chefe da Igreja revelou a associação entre o abuso e a destruição do meio ambiente e um processo ininterrupto de exclusão social das pessoas mais fracas e menos hábeis. A referida exclusão decorre de "uma ambição egoísta e ilimitada de poder e bem-estar material", consistindo em "uma negação total da fraternidade humana e um atentado gravíssimo aos direitos humanos e ao ambiente". Nesse contexto, quem mais sofre são os pobres, em razão de um motivo triplo:

são descartados pela sociedade, ao mesmo tempo são obrigados a viver de desperdícios, e devem injustamente sofrer as consequências do abuso do ambiente. Estes fenómenos constituem, hoje, a "cultura do descarte" tão difundida e inconscientemente consolidada.

O Pontífice clamou pela adoção de soluções urgentes e eficazes, fazendo referência específica à Agenda 2030 para o Desenvolvimento Sustentável e à Conferência de Paris sobre as alterações climáticas. Em contrapartida, asseverou que "não são suficientes os compromissos solenemente assumidos, embora constituam certamente um passo necessário para a solução dos problemas". Ressalvando que os problemas extrapolam os mencionados, pregou uma luta realmente eficaz na luta contra os flagelos da humanidade.

\begin{abstract}
O mundo pede vivamente a todos os governantes uma vontade efectiva, prática, constante, feita de passos concretos e medidas imediatas, para preservar e melhorar o ambiente natural e superar o mais rapidamente possível o fenómeno da exclusão social e económica, com suas tristes consequências de tráfico de seres humanos, tráfico de órgãos e tecidos humanos, exploração sexual de meninos e meninas, trabalho escravo, incluindo a prostituição, tráfico de drogas e de armas, terrorismo e criminalidade internacional organizada.
\end{abstract}

Francisco argumentou que a eficácia das ações políticas e econômicas depende de se ter "sempre presente que, antes e para além de planos e programas, existem mulheres e homens concretos, iguais aos governantes, que vivem, lutam e sofrem e que muitas vezes se vêem obrigados a viver miseravelmente, privados de qualquer direito". É preciso permitir a tais pessoas que sejam atores dignos dos seus próprios destinos - o que supõe e exige notadamente o direito à educação, inclusive para as mulheres.

O Pontífice asseverou que os governantes devem assegurar a todos uma base mínima material e espiritual, que permita tornar efetiva a dignidade humana e possibilite a formação 
e manutenção das famílias. A referida base mínima material seria, para ele, constituída por casa, trabalho e terra. De outra parte, a espiritual consistiria na "liberdade de espírito, que inclui a liberdade religiosa, o direito à educação e todos os outros direitos civis". Em resumo,

(...) estes pilares do desenvolvimento humano integral têm um fundamento comum, que é o direito à vida, e, em sentido ainda mais amplo, aquilo a que poderemos chamar o direito à existência da própria natureza humana.

Relembrando diversos argumentos de seu antecessor, Bento XVI, Francisco sustentou que "a defesa do ambiente e a luta contra a exclusão exigem o reconhecimento duma lei moral inscrita na própria natureza humana". Defendeu, assim, o reconhecimento de limites éticos naturais inultrapassáveis. Suscitando as palavras de Paulo VI na própria ONU, Bergoglio apelou à consciência moral do homem para que a genialidade humana - expressa no progresso e na ciência - seja bem aplicada, no sentido de ajudar a resolver, entre outras coisas, os graves desafios acima mencionados.

O Papa passou, então, a criticar a guerra, que, em sua opinião, "é a negação de todos os direitos e uma agressão dramática ao meio ambiente". Por essa razão, a busca por um desenvolvimento humano integral autêntico para todos demanda o esforço para evitar a guerra entre as nações e os povos. Assim, faz-se necessário garantir o domínio do direito e o recurso às negociações, à mediação e à arbitragem. Lembrou, ainda, da importância da Carta das Nações Unidas enquanto norma jurídica fundamental cuja observância enseja resultados de paz. Para Francisco, a paz, a solução pacífica das controvérsias e o desenvolvimento de relações amistosas entre as nações - indicados como basilares pela Carta das Nações Unidas - sofrem forte contraste e negação com a tendência à proliferação das armas, especialmente as nucleares e as de destruição em massa. Nesse sentido, ele promoveu o Tratado de NãoProliferação como forma de se afastar de um direito baseado sobre a ameaça da destruição recíproca. Celebrou, assim, acordo então recém-celebrado no Oriente Médio sobre a questão nuclear, enquanto "prova das possibilidades da boa vontade política e do direito, cultivados com sinceridade, paciência e constância". No entanto, o Pontífice lamentou a dolorosa situação do Oriente Médio, do Norte da África e de outros países deste continente,

onde os cristãos, juntamente com outros grupos culturais ou étnicos e também com aquela parte dos membros da religião maioritária que não quer deixar-se envolver pelo ódio e a loucura, foram obrigados a ser testemunhas da destruição dos seus lugares de culto, do seu património cultural e religioso, das suas casas e haveres, e foram postos perante a alternativa de escapar ou pagar a adesão ao bem e à paz com a sua própria vida ou com a escravidão.

Conclamou, assim, a comunidade internacional a fazer todo o possível para impedir e prevenir futuras violências sistemáticas contra minorias étnicas e religiosas e populações inocentes.

Do mesmo modo, o Papa condenou o narcotráfico. Segundo ele, trata-se de uma conflitualidade nem sempre explícita, mas que silenciosamente mata milhões e pessoas e vem acompanhada do tráfico de pessoas e armas, lavagem de dinheiro, exploração infantil entre 
outras. Denunciou, também, a existência de estruturas paralelas, decorrentes do tráfico e da corrupção, que põe em perigo a credibilidade das instituições.

Francisco concluiu sua intervenção defendendo que a fraternidade universal e o respeito à sacralidade da vida humana devem ser a base sobre a qual se ergue a "casa comum de todos os homens". Criticou, portanto, a consistente e contínua fragmentação social experimentada pelo mundo contemporâneo, aparentemente interligado.

Da análise do discurso pontifício, algumas observações podem ser feitas. Em primeiro lugar, depreende-se rapidamente que houve dois focos (distintos, porém interligados) principais no pronunciamento de Francisco: a proteção ambiental e o combate à exclusão social. Trata-se de temas já explorados por seu antecessor imediato, mas agora ainda mais aprofundados.

Conforme exposto, o Papa sustentou a existência de um "direito ao ambiente", na medida em que o homem é uma porção do ambiente - portanto uma lesão a este significa um dano àquele - e porque cada ser vivo possui em si mesmo um valor de existência, de vida, de beleza e de interdependência com outras criaturas. Bergoglio já havia demonstrado enfaticamente sua preocupação com o equilíbrio ecológico. Em abril de 2015, poucos meses antes da visita à Organização das Nações Unidas, o Chefe da Igreja publicou sua Carta Encíclica Laudato $\mathrm{Si}^{\prime}$, sobre o "cuidado da casa comum".

Antes de maiores comentários, permita-se uma pequena digressão. Laudato Si', que pode ser traduzido para "louvado sejas", vem de um cântico de São Francisco de Assis, no qual se expressava que a natureza - a casa comum da humanidade - pode ser comparada a uma irmã (com quem se partilha a existência) ou a uma mãe (que tem braços acolhedores). 0 referido santo demonstrou em sua vida grande sensibilidade com a pobreza e o desejo de integrar homem e natureza ${ }^{16}$. Por essas razões, é possível ter uma ideia bastante concreta sobre os motivos que levaram o atual Pontífice a escolher o seu nome. Na referida Encíclica, Francisco evidenciou o mal provocado por conta do uso irresponsável e do abuso dos bens naturais, cujas consequências são mais sentidas pelos mais pobres, abandonados e maltratados. Demonstrou ao mundo a necessidade urgente de cuidar da causa comum e de buscar um desenvolvimento sustentável e integral. Denunciou o que está a acontecer com o ambiente: poluição, mudanças climáticas, esgotamento de recursos naturais como a água, a perda da biodiversidade, a deterioração da qualidade de vida humana e degradação social, desigualdade planetária. Denotou especialmente sua preocupação com a fraqueza da reação política internacional - esta, muitas vezes, influenciada por interesses particulares e sujeita a manipulação pelos agentes econômicos. Por outro lado, reconheceu que a crise ecológica tem raiz humana, sendo notadamente fruto do paradigma tecnocrático dominante. Propôs, enfim, uma reflexão a respeito de uma "ecologia integral", que inclua claramente as dimensões humanas e sociais.

A ecologia integral de Francisco contempla diversas dimensões: ambiental, econômica e social (que considera as interações dos sistemas naturais com os sociais); cultural (cuidado com as riquezas históricas, culturais e arquitetônicas); quotidiana (relativa a poluição, acústica e outros fatores que influenciam na qualidade de vida).

${ }^{16}$ FRUGONI, Chiara. A vida de um homem: Francisco de Assis. Tradução: Federico Carotti. São Paulo: Companhia das Letras, 2011. 
Do mesmo modo, apela para uma ideia de justiça intergeracional, no sentido de preocupação e solidariedade para com aqueles que ainda hão de vir. Tudo isso exposto, percebese que, à ONU, o Papa mais uma vez sustentou que há uma única e complexa crise socioambiental, que não se confunde com duas crises separadas, uma social e outra ambiental. Exatamente por isso, a solução demanda uma abordagem integral que cuide da natureza e ao mesmo tempo promova o combate à exclusão.

Ademais, assim como seus antecessores, Bergoglio aproveitou o discurso à Assembleia Geral para pregar a favor da paz e do desarmamento e contra a guerra. Ele se preocupou especificamente em promover o Tratado de Não-Proliferação de Armas Nucleares. Não poderia ser diferente: "o caminho do desarmamento nuclear é lento e cheio de percalços, sendo notória a relutância das potências nucleares de assumirem compromisso claro e inequívoco de natureza multilateral quanto à eliminação de seus arsenais"17. Essa situação lembra muito o que João Paulo II denunciara em primeira sua intervenção à ONU, quando criticou a resistência às propostas concretas e efetivas de desarmamento, afirmando que "com a vontade de paz declarada por todos e pela maior parte desejada, coexiste, talvez escondido, talvez hipotético, mas real, o seu contrário e a sua negação" ${ }^{18}$.

A respeito do Oriente Médio, Francisco abordou duas questões. Em primeiro lugar, saudou o pacto que limita o programa nuclear iraniano, uma esperança de paz para a região. Entretanto, lastimou o fato de a população da região, assim como de partes do continente africano, estar sendo afetada pelas ações do Estado Islâmico, entidade violadora dos direitos humanos no plano físico, cultural, histórico...

Finalmente, testemunha-se no pronunciamento papal o combate de Francisco ao narcotráfico. Nos últimos anos, o Chefe da Igreja vem pregando contra o tráfico de drogas, em especial nas oportunidades que teve de visitar a América Latina (quando foi, por exemplo, ao México e à Colômbia, países em que os reflexos dos cartéis de drogas são cruelmente experimentados pela população, em especial a mais pobre).

\section{- CONSIDERAÇÕES FINAIS}

Da análise dos pronunciamentos de Paulo VI, João Paulo II, Bento XVI e Francisco à Assembleia da Organização das Nações Unidas, conclui-se que os referidos Pontífices não podem ser acusados de silenciar quanto às grandes questões que ameaçavam a humanidade nas respectivas oportunidades. Pelo contrário, todos pautaram seus discursos na efetiva defesa dos direitos humanos.

Paulo VI demonstrou ser um ferrenho defensor da paz, condenando abertamente a corrida armamentista e os conflitos bélicos que assolavam o mundo à época (em especial a

\footnotetext{
${ }^{17}$ LAFER, Celso. As novas dimensões do desarmamento: os regimes de controle das armas de destruição em massa $e$ as perspectivas para a eliminação das armas nucleares. 1998 . Disponível em: http://www.iea.usp.br/publicacoes/textos/laferdesarmamento.pdf. Acesso em 18 de janeiro de 2018.

${ }^{18}$ PAPA JOÃO PAULO II. Discurso do Papa João Paulo II na Assembleia Geral das Nações Unidas. Nova lorque, 02 de outubro de $1979 . \quad$ Disponível em: http://w2.vatican.va/content/john-paulii/pt/speeches/1979/october/documents/hf_jp-ii_spe_19791002_general-assembly-onu.html. Acesso em 31 de julho de 2017.
} 
Guerra Fria e a recém-iniciada Guerra do Vietnã). Também já defendia, desde meados da década de 1960, a necessidade de os países mais desenvolvidos auxiliarem os menos desenvolvidos no combate à pobreza, à fome, ao analfabetismo e às severas desigualdades sociais. Do mesmo modo, na sua posição de Chefe de uma das maiores religiões monoteístas do planeta, intercedeu a favor do direito à liberdade religiosa, reconhecido oficialmente pela Igreja, poucas semanas depois, na Declaração Dignitatis Humanae, do Concílio Vaticano II. Ressalte-se, todavia, a campanha de Paulo VI contra as técnicas de controle da natalidade (referidas no pronunciamento à ONU e aprofundadas em sua posterior Carta Encíclica Humanae Vitae, da qual se distanciou a caminhada histórica dos direitos humanos.

João Paulo II, por sua vez, em duas oportunidades demonstrou à ONU o seu papel de defensor dos direitos humanos. Em 1979, sublinhou a importância das Nações Unidas, de sua Carta e da DUDH na construção e na proteção da dignidade humana. Conclamou o mundo em especial o Oriente Médio - à paz, em especial a partir do desarmamento. Igualmente destacou a importância da liberdade religiosa, bem como da proteção aos explorados e excluídos, pregando o combate ao abismo entre os mais ricos e os mais pobres. Em 1995, João Paulo II focou nas questões de liberdade e tolerância. Sustentou a necessidade de haver pessoas e nações livres. Ademais, advogou pelo respeito ao outro e às diferenças, em busca da construção de uma sociedade pautada por paz, respeito e solidariedade.

Deve ser destacado, por fim, que os três discursos proferidos na segunda metade do século XX focaram especialmente em três questões, que, portanto, podem ser reconhecidas como a pauta internacional da Santa Sé na época: a paz, a liberdade religiosa e o combate às desigualdades sociais.

Por outro lado, a exposição dos pronunciamentos de Bento XVI e de Francisco à Organização das Nações Unidas faz concluir que, no início do século XXI, a Igreja Católica vem adotando como pauta principal de sua política externa - além da promoção da paz e do combate ao desarmamento e à pobreza, igualmente verificados nas posturas de Paulo VI e João Paulo Il quando compareceram à ONU - a proteção ambiental. Ambos os discursos pontifícios - cujas palavras são corroboradas pela postura dos mencionados Papas em diversas outras oportunidades - chamam atenção para a questão ecológica e para a defesa da "casa comum". Tanto Ratzinger quanto Bergoglio se referiram aos métodos científicos ora vigentes, apelando à consciência moral no exercício da ciência. Francisco, em outras ocasiões, denunciou uma "tecnocracia" vazia, que não leva em consideração os reflexos do progresso para as relações socioambientais. Trata-se, inegavelmente, de um tópico de direitos humanos ${ }^{19}$, inclusive porque ambos fundamentaram suas preocupações no fato de que, entre outros motivos, as lesões ao ambiente ensejam graves reflexos para a humanidade.

\section{REFERÊNCIAS}

AZEVEDO, Dermi. Desafios estratégicos da Igreja Católica. Lua Nova, n.60, 2003. Disponível em: http://www.scielo.br/pdf/\%0D/ln/n60/a04n60.pdf. Acesso em: 14 de janeiro de 2018.

19 SANTOS, Maureen; TRENTIN, Melisandra. Direito Humano ao Meio Ambiente. 2013. Disponível em: http://www.ritimo.org/Direito-Humano-ao-Meio-Ambiente. Acesso em 31 de julho de 2017. 
CORNWELL, John. O Papa de Hitler - a história secreta de Pio XII. Tradução de A.B. Pinheiro de Lemos. Rio de Janeiro: Imago Ed., 2000.

EISNER, Peter. A última cruzada do Papa: como um jesuíta norte-americano auxiliou a campanha de Pio XI para travar Hitler. Tradução de Pedro Saraiva. Lisboa: Gradiva, 2016.

FRUGONI, Chiara. A vida de um homem: Francisco de Assis. Tradução: Federico Carotti. São Paulo: Companhia das Letras, 2011.

GUARNIERI, Tathiana Haddad. Os direitos das mulheres no contexto internacional - da criação da ONU (1945) à Conferência de Beijing (1995). Revista Eletrônica da Faculdade Metodista Granbery, 2010. Disponível em: http://re.granbery.edu.br/artigos/MzUx.pdf. Acesso em 11 de janeiro de 2018.

JUBILUT, Liliana Lyra. A responsabilidade de proteger é uma mudança real para as intervenções humanitárias? 2008. Disponível em: http://centrodireitointernacional.com.br/static/revistaeletronica/artigos/Liliana\%20Jubilut\%20DIH.pdf. Acesso em 14 de janeiro de 2018.

KERTZER, David I. O papa e Mussolini: a conexão secreta entre Pio XI e a ascensão do fascismo na Europa. Tradução de Berilo Vargas. Rio de Janeiro: Intrínseca, 2017.

LAFER, Celso. As novas dimensões do desarmamento: os regimes de controle das armas de destruição em massa e as perspectivas para a eliminação das armas nucleares. 1998. Disponível em: http://www.iea.usp.br/publicacoes/textos/laferdesarmamento.pdf. Acesso em 18 de janeiro de 2018.

MACHADO, Diego Pereira. Sujeitos de direito internacional: Santa Sé e Vaticano. 2013. Disponível em: http://www.egov.ufsc.br/portal/conteudo/sujeitos-do-direito-internacional-santas\%C3\%A9-e-vaticano. Acesso em 09 de agosto de 2017.

MARQUES, Miguel Ângelo. A Santa Sé e o Estado da Cidade do Vaticano à Luz do Direito Internacional. 2017. Disponível em: https://revistas.pucsp.br/index.php/DIGE/article/download/32778/22630. Acesso em 31 de julho de 2017.

MUNHOZ, Sidnei José; ROLLO, José Henrique. DÉTENTE E DÉTENTES NA ÉPOCA DA GUERRA FRIA (DÉCADAS DE 1960 E 1970). Esboços - Revista do Programa de Pós-Graduação em História da UFSC, Florianópolis, v. 21, n. 32, p. 138-158, out. 2015. ISSN 2175-7976. Disponível em: https://periodicos.ufsc.br/index.php/esbocos/article/view/2175-7976.2014v21n32p138. Acesso em: 12 de janeiro de 2018.

PAPA BENTO XVI. Carta Encíclica Caritas in veritate sobre o desenvolvimento humano integral na caridade e na verdade. 2009. Disponível em: http://w2.vatican.va/content/benedictxvi/pt/encyclicals/documents/hf_ben-xvi_enc_20090629_caritas-in-veritate.html. Acesso em 15 de janeiro de 2018.

Discurso do Papa Bento XVI. Encontro com os Membros da Assembleia Geral das Nações Unidas. Nova lorque, 18 de abril de 2008. Disponível em: http://w2.vatican.va/content/benedict-xvi/pt/speeches/2008/april/documents/hf_ben-xvi_spe_20080418_un-visit.html. Acesso em 31 de julho de 2017.

PAPA FRANCISCO. Carta Encíclica Laudato Si' sobre o cuidado da Casa Comum. 2015. Disponível em: http://w2.vatican.va/content/francesco/pt/encyclicals/documents/papa-francesco_20150524_enciclica-laudato-si.html\#229. Acesso em 18 de janeiro de 2018. 
Discurso do Santo Padre. Visita à Organização das Nações Unidas. Nova lorque, 25 de setembro de 2015. Disponível em: http://w2.vatican.va/content/francesco/pt/speeches/2015/september/documents/papa-francesco_20150925_onu-visita.html. Acesso em 31 de julho de 2017.

PAPA JOÃO PAULO II. Address of His Holiness John Paul II. The fiftieth General Assembly of the United Nations Organization. New York, 05 October 1995. Disponível em: http://w2.vatican.va/content/john-paul-ii/en/speeches/1995/october/documents/hf_jp-

ii_spe_05101995_address-to-uno.html. Acesso em 31 de julho de 2017.

. Discurso do Papa João Paulo II na Assembleia Geral das Nações Unidas. Nova Iorque, 02 de outubro de 1979. Disponível em: http://w2.vatican.va/content/john-paul-ii/pt/speeches/1979/october/documents/hf_jp-ii_spe_19791002_general-assembly-onu.html. Acesso em 31 de julho de 2017.

PAPA PAULO VI. Carta Encíclica Humanae Vitae de Sua Santidade Papa Paulo VI sobre a regulação da natalidade. Roma, 1968. Disponível em: <http://w2.vatican.va/content/paul-

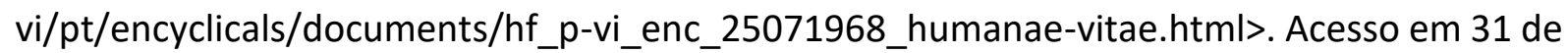
julho de 2017.

. Discurso do Papa Paulo VI na sede da ONU. Nova lorque, 4 de outubro de 1965. Disponível em: http://w2.vatican.va/content/paul-vi/pt/speeches/1965/documents/hf_pvi_spe_19651004_united-nations.html. Acesso em 31 de julho de 2017.

PAPA PIO XI. Carta Encíclica Mit Brennender Sorge. Cidade do Vaticano, 1937. Disponível em: http://w2.vatican.va/content/pius-xi/en/encyclicals/documents/hf_p-

xi_enc_14031937_mit-brennender-sorge.html. Acesso em 09 de agosto de 2017.

PORTILHO, Ana Cláudia. O ator santa sé na política internacional moderna. In: $3^{\circ}$ ENCONTRO NACIONAL ABRI 2001, 3., 2011, São Paulo. Proceedings online... Assosciação Brasileira de Relações Internacionais Instituto de Relações Internacionais - USP, Available from: http://www.proceedings.scielo.br/scielo.php?script=sci_art-

text\&pid=MSC0000000122011000100013\&lng=en\&nrm=abn. Acesso em 12 de Janeiro de 2018.

SANTOS, Maureen; TRENTIN, Melisandra. Direito Humano ao Meio Ambiente. 2013. Disponível em: http://www.ritimo.org/Direito-Humano-ao-Meio-Ambiente. Acesso em 31 de julho de 2017.

SOUZA, Ney de. Contexto e desenvolvimento histórico do Concílio Vaticano II. In: BOMBONATTO, V.; GONÇALVES, P.L. Concílio Vaticano II: análise e prospectivas. São Paulo: Paulinas, 2004. Disponível em: http://ciberteologia.paulinas.org.br/ciberteologia/wp-content/uploads/2009/05/contexto_desenvolvimento.pdf. Acesso em 11 de janeiro de 2018.

SOUZA, Salmo Caetano de. A Santa Sé e o Estado da Cidade do Vaticano: distinção e complementaridade. Revista da Faculdade de Direito da Universidade de São Paulo. v.100, 2005. Disponível em: http://www.revistas.usp.br/rfdusp/article/view/67675. Acesso em 31 de julho de 2017. 